\title{
Changes in the Content of Phenolic Compounds and Biological Activity in Traditional Mexican Herbal Infusions with Different Drying Methods
}

\author{
Sandra N. Jimenez-Garcia ${ }^{1}$, Moisés A. Vazquez-Cruz ${ }^{2}{ }^{\circledR}$, Xóchitl S. Ramirez-Gomez ${ }^{1}$, \\ Vicente Beltran-Campos ${ }^{1}$, Luis M. Contreras-Medina ${ }^{3}$, Juan F. Garcia-Trejo ${ }^{3}$ and \\ Ana A. Feregrino-Pérez ${ }^{3, *(\mathbb{D})}$ \\ 1 División de Ciencias de la Salud e Ingeniería, Campus Celaya-Salvatierra, C.A. Enfermedades no \\ transmisibles, Universidad de Guanajuato, Av. Ing. Javier Barros Sierra No. 201 Esq. Baja California, Ejido \\ de Santa Maria del Refugio Celaya, Guanajuato, C.P. 38140, Mexico; sandra_neli_j@hotmail.com (S.N.J.-G.); \\ xosofira2002@yahoo.com.mx (X.S.R.-G.); drvbeltranc@hotmail.com (V.B.-C.) \\ 2 Departamento de Investigación y Desarrollo, KOPPERT MEXICO, Circuito el Marques Nte. 82, Parque \\ industrial El Marqués, Santiago de Querétaro, C.P. 76246, Mexico; mvazquez@koppert.com.mx \\ 3 División de Estudios de Posgrado, C.A. Bioingeniería, Básica y Aplicada Facultad de Ingeniería, Universidad \\ Autónoma de Querétaro, C.U. Cerro de las Campanas S/N, Colonia Las Campanas, Santiago de Querétaro, \\ Querétaro, C.P. 76010, Mexico; miguel.contreras@uaq.mx (L.M.C.-M.); fernando.garcia@uaq.mx (J.F.G.-T.) \\ * Correspondence: feregrino.angge@hotmail.com; Tel.: +442-192-12-11 (ext. 6016)
}

Received: 14 March 2020; Accepted: 30 March 2020; Published: 31 March 2020

\begin{abstract}
Mexican spices are used in the supplementation of the human diet and as medicinal herbs for the particularly high amounts of compounds capable of deactivating free radicals. In addition, these spices can have beneficial effects on chronic, no-transmissible diseases such as type II diabetes and hypertension arterial. The objective of this study is to determine the content of phenolic compounds on the antioxidant activity and inhibitory enzymes of $\alpha$-amylase, $\alpha$-glucosidase and angiotensin-converting enzyme in melissa, peppermint, thyme and mint, which are subjected to microwave drying, conventional and freeze-drying to be used as alternative treatments. Spices were evaluated to determine total phenols, flavonoids, tannins, 2,2-Diphenyl-1-picrylhydrazyl (DPPH), (2,2'-azino-bis- (3-ethyl benzothiazolin-6-ammonium sulphonate) (ABTS) and Ferric Reducing/Antioxidant Power (FRAP), enzymatic activity. The investigation showed that conventional drying caused a decrease in antioxidant properties and inhibitory activity, in some species, while remained preserved in microwave drying and freeze-drying. The activity of polyphenol oxides and peroxidase decreases with high temperatures and these increase with the use of cold temperatures. This study aims to determine the extent of optimal drying required to preserve phenolic compounds, and the positive effect on antioxidant activity and enzymatic activity in in vitro models, which will produce benefits for the infusion processing industry and the pharmaceutical industry.
\end{abstract}

Keywords: phenolic compounds; biological activity; drying processes

\section{Introduction}

The use of traditional medicinal herbs has become of daily use today. Most people prefer to use medicinal herbs that contain especially high amounts of compounds, capable of deactivating free radicals and generating health benefits, safety and efficacy, compared to pharmaceuticals. Some pharmaceutical products use plant extracts as raw material, in order to produce new medicines or as an active ingredient of existing medicines. On the other hand in developing countries, approximately $80 \%$ of the population depends on medicinal herbs for primary care, as well as in Oriental or Native 
American medicine [1]. One of the plants most commonly used as infusions of medicinal herbs in Mexico are herbs or spices that belong to the Lamiaceae family, as well as Melissa (Melissa officinalis), thyme (Thymus vulgaris L.), peppermint (Mentha spicata), and mint (Mentha x piperita). Its aerial parts, especially the leaves and flowers, are rich in secondary metabolites, such as tannins, rosmarinic acid, flavonoids, luteolin, apigenin, and phenolic compounds, essential oil, among other phytochemical compounds [2-4]. The benefits derived from the use of natural products, that are rich in bioactive substances, have promoted a growing interest in the pharmaceutical industries. Plants contain a wide variety of phytochemicals, antioxidants or bioactive molecules, which can counteract free radicals, and thus, retard the progress of many chronic diseases associated with oxidative stress and reactive oxygen species [5,6]. The consumption of infusions, or foods high in antioxidants, has been associated with beneficial effects against cancer, cardiovascular diseases, diabetes and other diseases associated with aging [7]. Therefore, antioxidants protect against free radicals derived from the glycation of non-enzymatic proteins, oxidative stress. Moreover, they accelerate in hyperglycemic conditions, causing complications in diabetic people, thus, humans have proposed as agents therapeutic to various herbs and spices. Furthermore, the antioxidant activity of herbs and spices, associated with type 2 diabetes, may be a primary factor in vascular diseases that diabetics often develop [8]. Due to the different effects of advanced protein glycation in diabetes and the pathologies caused by age, it has been proposed that the inhibition of glycation can prevent the progression of different pathologies of diabetic complications and delay aging [9-11]. Therefore, studies have focused on the characterization of phenolic and other phytochemical compounds with biological activity, which are supplied to human organisms as food components or as specific preventive pharmaceutical products, and can improve glucose metabolism, as well as the general health of diabetic patients $[12,13]$. Herbs and spices are generally used as infusions or as condiments in foods, are considered nutraceuticals concerning their nutritional, medicinal and therapeutic properties and, on the other hand, they also improve the taste of food, prolong shelf life by producing an antimicrobial activity $[14,15]$. The leaves of herbs and spices are processed before they are ready to be packaged. Drying the herb leaves is usually done to preserve the leaves, and thereby, increasing their shelf life $[15,16]$. Drying methods that are used, include air drying, sun drying, freeze-drying, oven drying, and microwave drying [17-19]. Drying removes water content by transferring the moisture content of the material to the surface, which prevents unwanted microbial growth, while increasing the stability of the phenolic compounds in the leaves [20]. It is a critical process, given it is the process is known to affect the antioxidant properties of the leaves due to thermal degradation and/or the action of oxidative enzymes [21]. Polyphenol oxidase is the oxidative enzyme degrading phenolic compounds, while peroxidase is related to phytochemical degradation in the presence of hydrogen peroxide, which plays a role in the degradation of phenolic compounds in plant leaves produced by different types of drying [22].

Research efforts have been currently oriented to the use of natural products, particularly plant foods or extracts in the management of chronic-degenerative diseases, such as the management of diabetes, high blood pressure, and other health-related challenges, as well as the conservation of these plant foods, which has deepened in the drying processes $[19,23,24]$. Therefore, the processes of drying herbs inhibit microbial growth and prevent certain biochemical changes but, at the same time, can lead to other alterations that affect the quality of the herb, such as changes in appearance and alterations of volatile compounds, reactions of oxidation or esterification reactions, and also, the increase in phytochemical compounds, such as eugenol, sesquiterpenes, and some phenolic compounds $\mathrm{h}$ [25]. Drying is necessary as a means to remove moisture and ensure that the product is enzymatically and microbiologically stable. However, previous research has also focused on the drying of various herbs associated with highly biologically active components [26]. Approximately $85 \%$ of these traditional herbs contain phytochemicals, which confers beneficial effects on health. The drying of aromatic herbs are considered a parameter for measuring quality, and water removal of the aromatic herbs are related to the drying methods. The production of new compounds can take place during drying. Any drying technology, innovative or traditional, that promotes an increase in bioactive potential would be of 
interest. The indicators commonly used to determine the quality of dried herbs, include sensory characteristics, structural properties and bioactive compounds, among others [27]. Microwave drying, conventional, freeze-drying are innovative, new and existing drying technologies, used in herbs or biomaterial processing, which help preserve biologically active components, and are an important aspect to be taken into account when applying a certain method of dried. Over the years, research have focused on studying the influence of drying on the chemical changes of various products. However, most previous studies have considered the effects of drying on antioxidant properties and content of essential oils [28]. Therefore, this document critically and comprehensively analyzes the effects of drying methods on the bioavailability of phenolic compound of various herbs. The objective of this paper is to review the influence of different drying methods on antioxidant activities, enzyme activity, and the contents of the phenolic compound of various herbs. Also, the advantages and limitations of the drying methods, used in this research, are analyzed in detail. Therefore, this paper aims to study the changes in the contents of the phenolic compounds of methanolic extracts to quantify different antioxidant compounds and bioactive compounds in Melissa, thyme, peppermint and mint in three drying methods, conventional, microwave, and freeze-drying. A study is also conducted to explore its health benefits and the effects of treatments and different types of spices.

\section{Results}

\subsection{Quantification of Phenolic Compounds in Herbs and Spices}

Data collected for phenolic compounds, which corresponded to the samples, were analyzed in the different drying treatments applied to the species. The identification of phytochemicals nowadays appears to be central in detecting the set of bioactive compounds in plants, as well as elucidating their antioxidant capacity and their bioactive capacity. Phenolic compounds are an efficient way to describe the interpretation of plant protective metabolites and the effect they can have on some chronic non transmissible diseases. With respect to the origin of the data shown in Table 1, the analysis of variance performed on the data for phenolic extraction showed a significant difference in the phenolic compounds by plant material in Melissa and thyme with a strong influence of the drying method by microwave and freeze-drying methods. Therefore, it can be observed that for 2 vegetative material analyzed such as Melissa and thyme, the greatest extraction of these compounds was achieved by the microwave drying with 0.5491 , and $0.5343 \mathrm{mg} \mathrm{GAE} / \mathrm{g} \mathrm{DW}(\mathrm{F}=13.492 ; \mathrm{P}=0.000)$, respectively and freeze-drying method with 0.2897 , and $0.3132 \mathrm{mg} \mathrm{GAE} / \mathrm{g} \mathrm{DW}(\mathrm{F}=15.407 ; \mathrm{P}=0.000)$ for Melissa, and Thyme, respectively. Peppermint showed significant difference in conventional drying with $0.1200 \mathrm{mg} \mathrm{GAE} / \mathrm{g}$ DW $(\mathrm{F}=27.695 ; \mathrm{P}=0.000)$. Peppermint concentrated the content of phenolic compounds up to $97 \%$ with the freeze-drying method and $95 \%$ with the microwave drying method, which indicates the appropriateness of these methods for the extraction of this functional compound. It is important to mention that the conventional drying method was the only method that caused a decrease in the concentration of phenolic compounds in peppermint, thyme, and mint by $16 \%$, $5.0 \%$, and $6.0 \%$, respectively. The above gives indications of the susceptibility of these compounds to decomposition, employing a drying method where heat is used to carry out the drying process. 
Table 1. Phenolic compounds content in methanol extracts in Melissa, peppermint, thyme, and mint.

\begin{tabular}{|c|c|c|c|c|c|c|c|c|c|c|c|c|c|c|c|c|c|c|}
\hline \multirow{2}{*}{$\begin{array}{c}\text { Melissa } \\
\text { Drying } \\
\text { Method }\end{array}$} & \multicolumn{6}{|c|}{ Phenolic mg GAE/g DW } & \multicolumn{6}{|c|}{ Flavonoids mg RE/g DW } & \multicolumn{6}{|c|}{ Tannins mg CE/g DW } \\
\hline & & & & & $\mathbf{F}$ & $p$-Value * & & & & & $\mathbf{F}$ & $p$-Value * & & & & & $\mathbf{F}$ & $p$-Value * \\
\hline Fresh plant & 0.4452 & \pm & 0.0319 & a & & & 0.5308 & \pm & 0.0437 & a & & & 0.0005 & \pm & 0.000 & a & & \\
\hline $\begin{array}{c}\text { Microwave } \\
\text { oven }\end{array}$ & 0.5491 & \pm & 0.0419 & $\mathrm{~b}$ & 13.492 & 0.000 & 0.5520 & \pm & 0.0455 & a & 0.471 & 0.706 & 0.0016 & \pm & 0.001 & c & 457.046 & 0.000 \\
\hline Conventional & 0.4452 & \pm & 0.0053 & a & & & 0.5262 & \pm & 0.0216 & a & & & 0.0028 & \pm & 0.002 & d & & \\
\hline Freeze-drying & 0.5343 & \pm & 0.0408 & $\mathrm{~b}$ & & & 0.5262 & \pm & 0.0433 & a & & & 0.0011 & \pm & 0.000 & $\mathrm{~b}$ & & \\
\hline \multicolumn{19}{|c|}{ Peppermint } \\
\hline Fresh plant & 0.14030 & \pm & 0.00493 & $\mathrm{a}$ & & & 0.22140 & \pm & 0.02005 & $\mathrm{a}$ & & & 0.04905 & \pm & 0.00392 & $\mathrm{~b}$ & & \\
\hline $\begin{array}{c}\text { Microwave } \\
\text { oven }\end{array}$ & 0.14800 & \pm & 0.00649 & a & 27.695 & 0.000 & 0.25058 & \pm & 0.02269 & a & 2.359 & 0.102 & 0.00170 & \pm & 0.00011 & a & 853.154 & 0.000 \\
\hline Conventional & 0.12000 & \pm & 0.00526 & $\mathrm{~b}$ & & & 0.23885 & \pm & 0.02163 & a & & & 0.00321 & \pm & 0.00017 & a & & \\
\hline Freeze-drying & 0.14400 & \pm & 0.00631 & a & & & 0.25006 & \pm & 0.02265 & $\mathrm{a}$ & & & 0.00196 & \pm & 0.00006 & $\mathrm{a}$ & & \\
\hline \multicolumn{19}{|l|}{ Thyme } \\
\hline Fresh plant & 0.24804 & \pm & 0.01869 & $\mathrm{a}$ & & & 0.93051 & \pm & 0.04695 & $\mathrm{a}$ & & & 0.01232 & \pm & 0.00124 & c & & \\
\hline $\begin{array}{l}\text { Microwave } \\
\text { oven }\end{array}$ & 0.28973 & \pm & 0.02459 & $\mathrm{~b}$ & 15.407 & 0.000 & 0.93051 & \pm & 0.04695 & $\mathrm{a}$ & 125.032 & 0.000 & 0.00072 & \pm & 0.00003 & a & 501.007 & 0.000 \\
\hline Conventional & 0.23492 & \pm & 0.01994 & a & & & 0.79758 & \pm & 0.04024 & $\mathrm{~b}$ & & & 0.00064 & \pm & 0.00005 & a & & \\
\hline Freeze-drying & 0.31323 & \pm & 0.02658 & $\mathrm{~b}$ & & & 0.53172 & \pm & 0.02683 & c & & & 0.00224 & \pm & 0.00004 & $\mathrm{~b}$ & & \\
\hline \multicolumn{19}{|l|}{ Mint } \\
\hline Fresh plant & 0.10504 & \pm & 0.07925 & $\mathrm{a}$ & & & 0.77346 & \pm & 0.00773 & c & & & 0.00042 & \pm & 0.00042 & $\mathrm{a}$ & & \\
\hline $\begin{array}{c}\text { Microwave } \\
\text { oven }\end{array}$ & 0.10162 & \pm & 0.10425 & $\mathrm{a}$ & 0.054 & 0.983 & 0.87538 & \pm & 0.00875 & a & 200.684 & 0.000 & 0.00004 & \pm & 0.00004 & $\mathrm{ab}$ & 4.988 & 0.010 \\
\hline Conventional & 0.09887 & \pm & 0.10144 & $\mathrm{a}$ & & & 0.81896 & \pm & 0.00819 & $\mathrm{~b}$ & & & 0.00028 & \pm & 0.00028 & $\mathrm{~b}$ & & \\
\hline Freeze-drying & 0.12084 & \pm & 0.12398 & a & & & 0.87356 & \pm & 0.00873 & $\mathrm{a}$ & & & 0.00016 & \pm & 0.00016 & a & & \\
\hline
\end{tabular}

mg GAE/g DW (mg Gallic acid equivalents/g dry weight), mg RE/g DW (routine equivalents/g dry weight), mg CE/g DW (mg catechin equivalents/g dry weight). The average value of 4 $\mathrm{mg}$ GAE/g DW (mg Gallic acid equivalents/g dry weight), $\mathrm{mg}$ RE/g DW (routine equivalents/g dry weight), $\mathrm{mg} \mathrm{CE} / \mathrm{g}$ DW (mg catechin equivalents/g dry weight). The average value of 4
treatments, 3 repetitions. General multivariate linear model. * Comparison between means (Tukey $\alpha \leq 0.05$ ). Digits with equal letters in the same column are not statistically different. Different letters in the column indicate what are statistically different. 
On the other hand, the results for the concentration of flavonoids, between drying methods, are shown in Table 1. Highly significant differences were observed between treatments. Again, microwave drying method and freeze-drying shows the best results for flavonoid extraction. In the case of thyme showed significant difference in the microwave drying method $0.93051 \mathrm{mgRE} / \mathrm{g} \mathrm{DW}$ ( $\mathrm{F}=125.032 ; \mathrm{P}=0.000)$ and for the mint showed significant difference in the microwave drying method and freeze-drying $0.87538 \mathrm{mg} \mathrm{RE} / \mathrm{g}$ DW and $0.87356 \mathrm{mg} \mathrm{RE} / \mathrm{g} \mathrm{DW}(\mathrm{F}=200,684 ; \mathrm{P}=0.000)$ respectively. Microwave drying and freeze-drying methods allowed the flavonoid concentration to be increased by $88 \%$ in mint. However, it is important to note that freeze-drying is not recommended for the quantification of these compounds. Thyme showed a reduction in the flavonoid's contents, compared to the treatment of fresh plant material, and the concentration was reduced to a $75 \%$.

In the case of tannin extraction, significant differences were found between the drying methods evaluated. For most of the plant materials evaluated, freeze-drying was the better drying method. Thyme showed a concentration of $0.00224 \mathrm{mgCE} / \mathrm{g} \mathrm{DW}(\mathrm{F}=501.007 ; \mathrm{P}=0.000)$. In peppermint, thyme, and mint, fresh plant material showed the highest concentrations. Unlike the phenolic and flavonoid compounds, none of the drying methods, used in the extraction of tannins, resulted an increase in the concentration of these compounds, and otherwise showed that the tannins are more sensitive to any drying method.

\subsection{Analysis of the Different Antioxidant Capacity in Herbs and Spices}

Data collected from the three different techniques were analyzed to determine antioxidant capacity, as shown in Table 2. The extraction by DPPH in the different drying methods showed highly significant differences. The freeze-drying method showed the highest concentration of DPPH for lemon balm and mint with $73.5 \%$, and $77.5 \%$, respectively, followed by the conventional drying method for thyme and mint $75.6 \%$, and $76.4 \%$, respectively. Otherwise, mint and peppermint showed a decrease DPPH concentration with respect to fresh plant material by $45 \%$. The highest antioxidant capacity was shown in peppermint by the conventional drying method by $78 \%(\mathrm{~F}=37.2 ; \mathrm{P}=0.000)$. On the other hand, the ABTS method illustrated the different plant materials showing significant differences in freeze-drying in three spices, such as, Melissa, peppermint and thyme. A decrease in antioxidant capacity was observed in peppermint by ABTS through the microwave drying method and conventional drying, compared to fresh plant material with $52 \%$, and $40 \%$ respectively. This showed that peppermint could be more sensitive to the temperature changes used for the drying method. The highest antioxidant capacity by ABTS was shown by the conventional drying method in peppermint by $79 \%(F=17.8 ; \mathrm{P}=0.000)$. Finally, for the FRAP method, the different drying methods showed a significant difference in the plant materials in the microwave drying method. A decrease in antioxidant capacity in Melissa and thyme was observed in the conventional drying method compared to fresh plant material with $88.5 \%$, and $87 \%$, respectively. This indicates that compounds with the ability to trap free radicals are more sensitive to heat and are, therefore, not determined as a drying method in this plant material. The plant materials with highest antioxidant capacity were the four spices (Melissa, peppermint, thyme and mint) in microwave drying method by $90 \%(\mathrm{~F}=12.6 ; \mathrm{P}=0.000), 89 \%(\mathrm{~F}=10.9$; $\mathrm{P}=0.000), 83 \%(\mathrm{~F}=48.7 ; \mathrm{P}=0.000)$, and $88 \%(\mathrm{~F}=11.7 ; \mathrm{P}=0.000)$ respectively. 
Table 2. Antioxidant capacity of secondary metabolites in methanol extracts in melissa, peppermint, thyme, and mint.

\begin{tabular}{|c|c|c|c|c|c|c|c|c|c|c|c|c|c|c|c|c|c|c|}
\hline \multirow{2}{*}{\begin{tabular}{l}
\multicolumn{1}{c}{ Melissa } \\
Drying \\
Method
\end{tabular}} & & \multicolumn{5}{|c|}{ DPPH \% } & \multicolumn{6}{|c|}{ ABTS \% } & \multicolumn{6}{|c|}{ FRAP \% } \\
\hline & & & & & F & $p$-Value * & & & & & F & $p$-Value * & & & & & F & $p$-Value * \\
\hline fresh plant & 6.3 & \pm & 0.4 & d & 23.4 & 0.000 & 36.3 & \pm & 0.11 & d & 71.1 & 0.000 & 78.5 & \pm & 0.1 & $\mathrm{~b}$ & 12.6 & 0.000 \\
\hline $\begin{array}{l}\text { Microwave } \\
\text { oven }\end{array}$ & 41.8 & \pm & 0.7 & c & & & 39.9 & \pm & 0.4 & c & & & 89.5 & \pm & 0.3 & a & & \\
\hline Conventional & 73.5 & \pm & 0.2 & $\mathrm{~b}$ & & & 48.3 & \pm & 0.1 & $\mathrm{~b}$ & & & 9.3 & \pm & 0.9 & d & & \\
\hline Freeze-drying & 73.5 & \pm & 0.1 & a & & & 55.7 & \pm & 0.3 & a & & & 49.2 & \pm & 0.2 & c & & \\
\hline \multicolumn{19}{|c|}{ Peppermint } \\
\hline fresh plant & 40.4 & \pm & 0.8 & c & 37.2 & 0.000 & 64.8 & \pm & 0.7 & $\mathrm{~b}$ & 17.8 & 0.000 & 56.2 & \pm & 0.1 & $\mathrm{~b}$ & 10.9 & 0.000 \\
\hline $\begin{array}{l}\text { Microwave } \\
\text { oven }\end{array}$ & 22.4 & \pm & 0.2 & d & & & 31.4 & \pm & 0.1 & d & & & 89.1 & \pm & 0.1 & a & & \\
\hline Conventional & 71.3 & \pm & 0.0 & $\mathrm{~b}$ & & & 39.1 & \pm & 0.3 & c & & & 47.6 & \pm & 0.2 & d & & \\
\hline Freeze-drying & 77.5 & \pm & 0.3 & a & & & 78.8 & \pm & 0.2 & a & & & 54.0 & \pm & 0.5 & c & & \\
\hline \multicolumn{19}{|l|}{ Thyme } \\
\hline fresh spices & 6.64 & \pm & 0.4 & d & 36.6 & 0.000 & 34.3 & \pm & 0.4 & d & 20.2 & 0.019 & 57.5 & \pm & 0.4 & $\mathrm{~b}$ & 48.7 & 0.000 \\
\hline $\begin{array}{l}\text { Microwave } \\
\text { oven }\end{array}$ & 32.0 & \pm & 0.6 & c & & & 62.7 & \pm & 0.3 & a & & & 82.5 & \pm & 0.0 & a & & \\
\hline Conventional & 75.4 & \pm & 0.1 & $\mathrm{a}$ & & & 52.1 & \pm & 0.1 & c & & & 7.4 & \pm & 0.3 & d & & \\
\hline Freeze-drying & 74.4 & \pm & 0.1 & $\mathrm{~b}$ & & & 56.2 & \pm & 0.1 & $\mathrm{~b}$ & & & 53.6 & \pm & 0.0 & c & & \\
\hline \multicolumn{19}{|l|}{ Mint } \\
\hline fresh plant & 22.4 & \pm & 0.3 & d & 78.6 & 0.015 & 40.4 & \pm & 0.3 & d & 44.7 & 0.000 & 74.3 & \pm & 0.4 & $\mathrm{~b}$ & 11.7 & 0.000 \\
\hline $\begin{array}{c}\text { Microwave } \\
\text { oven }\end{array}$ & 39.5 & \pm & 0.2 & c & & & 53.3 & \pm & 0.4 & $\mathrm{~b}$ & & & 88.1 & \pm & 0.2 & a & & \\
\hline Conventional & 76.4 & \pm & 0.2 & a & & & 49.4 & \pm & 0.3 & c & & & 42.7 & \pm & 0.2 & d & & \\
\hline Freeze-drying & 68.6 & \pm & 0.2 & $\mathrm{~b}$ & & & 74.0 & \pm & 0.4 & $\mathrm{a}$ & & & 68.22 & \pm & 0.0 & c & & \\
\hline
\end{tabular}

The average value of 4 treatments, 3 repetitions. General multivariate linear model. * Comparison between means (Tukey $\alpha \leq 0.05)$. Digits with equal letters in the same column are not statistically different. Different letters in the column indicate what are statistically different. 


\subsection{Analysis of Bioactive Compounds of Herbs and Spices}

Table 3 shows the plant materials in relation to the different drying method, in the inhibition of $\alpha$-amylase, the samples show significant differences both in the plant material and in the drying method. In the factorial analysis, significant differences in the freeze-drying method were observed in the Melissa plant with $84 \%$ inhibition ( $F=24.0 ; \mathrm{P}=0.000)$, increasing the inhibition capacity of $\alpha$-amylase compared to fresh plant material in a $22 \%$, On the other hand, peppermint did not show significant differences between the drying methods, but it did reflect a decrease in the percentage of inhibition in the microwave drying method with respect to the control by $65 \%$. Likewise, in thyme and mint, there were no significant differences in the samples, and it behaves in the same way as peppermint. Thereby, the inhibition of $\alpha$-glucosidase is affected by the drying method used in plant materials, and there is an inhibition of this enzyme in microwave drying methods in the four plant materials studied. As shown in Table 3 in Melissa, significant differences were not observed in microwave drying method in regard to fresh plant material. However, a decrease in $\alpha$-glucosidase inhibition was shown in conventional drying by $44 \%$ compared to the fresh plant material. On the other hand, peppermint showed not greater inhibitory power on the $\alpha$-glucosidase enzyme, by not showing a significant difference in the microwave drying method. Furthermore, freeze-drying suffers a decrease in this inhibitory activity. On the other hand, the conventional drying method showed to be more sensitive in regard to fresh plant material by $50 \%$ inhibition. Therefore, the heat used for the conventional drying method decreases phytochemical compounds with the ability to inhibit enzymes important in chronic degenerative diseases. Likewise, thyme and mint show no significant differences in the inhibition of the $\alpha$-glucosidase enzyme. However, to finish the biological activities on the inhibition of the angiotensin-converting enzyme, the drying method that demonstrated the greatest effect was microwave drying method in Melissa, and mint with 55\% ( $\mathrm{F}=43.1 ; \mathrm{P}=0.000), 72 \%(\mathrm{~F}=180.8$; $\mathrm{P}=0.000$ ), respectively. A decrease in the inhibition of angiotensin-converting enzyme in peppermint was also observed over the conventional and freeze-drying method by $46 \%$, and $10 \%$, respectively. In freeze-drying, $g$, the inhibition of angiotensin-converting enzyme was reduced by $6 \%$ with respect to fresh plant materials. 
Table 3. Biological activity of secondary metabolites in methanol extracts in melissa, peppermint, thyme, and mint.

\begin{tabular}{|c|c|c|c|c|c|c|c|c|c|c|c|c|c|c|c|c|c|c|}
\hline \multirow{2}{*}{$\begin{array}{c}\text { Melissa } \\
\text { Drying } \\
\text { Method }\end{array}$} & \multicolumn{6}{|c|}{$\alpha$-Amylase \% } & \multicolumn{6}{|c|}{$\alpha$-Glucosidase $\%$} & \multicolumn{6}{|c|}{ ACE \% } \\
\hline & & & & & F & $p$-Value * & & & & & F & $p$-Value * & & & & & F & $p$-Value * \\
\hline Fresh plant & 50.3 & \pm & 16.3 & $\mathrm{ab}$ & & & 70.5 & \pm & 1.3 & $\mathrm{a}$ & & & 7.73 & \pm & 0.6 & a & & \\
\hline $\begin{array}{c}\text { Microwave } \\
\text { oven }\end{array}$ & 26.9 & \pm & 6.0 & $\mathrm{~b}$ & 10.1 & 0.000 & 69.6 & \pm & 3.7 & $\mathrm{a}$ & 40.5 & 0.000 & 27.9 & \pm & 7.4 & $\mathrm{~b}$ & 43.1 & 0.000 \\
\hline Conventional & 19.8 & \pm & 1.3 & $\mathrm{~b}$ & & & 47.6 & \pm & 1.0 & $\mathrm{~b}$ & & & 54.7 & \pm & 2.0 & c & & \\
\hline Freeze-drying & 84.1 & \pm & 3.6 & a & & & 31.0 & \pm & 3.9 & c & & & 72.6 & \pm & 4.4 & $\mathrm{~d}$ & & \\
\hline \multicolumn{19}{|l|}{ Peppermint } \\
\hline Freshplant & 94.5 & \pm & 1.7 & $\mathrm{a}$ & & & 48.7 & \pm & 6.0 & $\mathrm{ab}$ & & & 54.6 & \pm & 2.2 & $\mathrm{~b}$ & & \\
\hline $\begin{array}{c}\text { Microwave } \\
\text { oven }\end{array}$ & 32.2 & \pm & 10.5 & c & 24.0 & 0.000 & 62.2 & \pm & 2.3 & $\mathrm{a}$ & 17.2 & 0.000 & 84.3 & \pm & 5.9 & c & 41.4 & 0.000 \\
\hline Conventional & 85.4 & \pm & 1.3 & $\mathrm{ab}$ & & & 26.5 & \pm & 1.0 & c & & & 29.5 & \pm & 2.0 & $\mathrm{a}$ & & \\
\hline Freeze-drying & 71.3 & \pm & 3.2 & $\mathrm{~b}$ & & & 46.9 & \pm & 2.7 & $\mathrm{~b}$ & & & 49.2 & \pm & 2.3 & $\mathrm{~b}$ & & \\
\hline \multicolumn{19}{|l|}{ Thyme } \\
\hline Fresh plant & 24.0 & \pm & 8.2 & c & & & 50.7 & \pm & 3.2 & $\mathrm{ab}$ & & & 3.0 & \pm & 0.5 & $\mathrm{a}$ & & \\
\hline $\begin{array}{l}\text { Microwave } \\
\text { oven }\end{array}$ & 57.8 & \pm & 7.2 & $\mathrm{~b}$ & 23.1 & 0.000 & 63.0 & \pm & 2.8 & a & 4.1 & 0.019 & 20.9 & \pm & 2.8 & $\mathrm{~b}$ & 20.6 & 0.000 \\
\hline Conventional & 91.3 & \pm & 1.5 & $\mathrm{a}$ & & & 46.3 & \pm & 3.1 & $\mathrm{~b}$ & & & 8.5 & \pm & 2.2 & $\mathrm{a}$ & & \\
\hline Freeze-drying & 69.9 & \pm & 3.9 & $\mathrm{ab}$ & & & 56.6 & \pm & 4.6 & $\mathrm{ab}$ & & & 19.8 & \pm & 1.1 & $\mathrm{~b}$ & & \\
\hline \multicolumn{19}{|l|}{ Mint } \\
\hline Fresh plant & 35.1 & \pm & 10.8 & $\mathrm{ab}$ & & & 39.1 & \pm & 3.7 & $\mathrm{~b}$ & & & 49.3 & \pm & 0.9 & $\mathrm{~b}$ & & \\
\hline $\begin{array}{l}\text { Microwave } \\
\text { oven }\end{array}$ & 54.0 & \pm & 14.1 & $\mathrm{ab}$ & 4.4 & 0.015 & 64.1 & \pm & 3.9 & $\mathrm{a}$ & 14.1 & 0.000 & 71.9 & \pm & 1.4 & c & 180.8 & 0.000 \\
\hline Conventional & 24.5 & \pm & 7.0 & $\mathrm{~b}$ & & & 58.5 & \pm & 1.7 & $\mathrm{a}$ & & & 14.4 & \pm & 0.9 & $\mathrm{a}$ & & \\
\hline Freeze-drying & 74.2 & \pm & 7.8 & $\mathrm{a}$ & & & 46.4 & \pm & 1.9 & $\mathrm{~b}$ & & & 46.2 & \pm & 2.9 & $\mathrm{~b}$ & & \\
\hline
\end{tabular}

The average value of 4 treatments, 3 repetitions. General multivariate linear model. ${ }^{*}$ Comparison between means (Tukey $\alpha \leq 0.05$ ). Digits with equal letters in the same column are not statistically different. Different letters in the column indicate what are statistically different. 


\subsection{Analysis Comparative of Phytochemical Compounds in Different Plant Materials by Drying Method Using PCA.}

The analysis of the phytochemical compounds allowed us to identify the different compounds that were maintained after applying the drying method by plant material, the phytochemical compounds were the first analyzed by PCA, separating compounds by drying method. The analysis of the phenolic compounds is shown in (Figure 1). The two principal components (PC) described 78.8\% of the variation among drying methods. PC1 describes 36\% variation, whereas PC2 described 60.4\%. Flavonoids in Melissa, peppermint, and mint, as well as the phenolic compounds in Melissa, peppermint and thyme described a positive variation in PC1 grouping in the drying methods with conventional drying method and freeze-drying. PC2 was described by Melissa and mint tannins grouped in conventional drying method. The drying methods that had of the greatest effect phenolic compounds were grouped into the microwave drying and freeze-drying methods. In the case of antioxidant capacity, the PCA showed that the first two principal components PC described 93.5\% of the variation (Figure 2). In relation to antioxidant capacity, PC1 describes $44.9 \%$ of the variation, group the method by ABTS in the four plant materials studied, as well as the DPPH in Melissa, thyme, and mint. Whereas, PC2 describes $83.5 \%$ of the variation in the method by FRAP in the four plant materials. Grouping the three methods of quantification of antioxidant capacity in the microwave drying method. In the case of biological activity, the PCA showed that the first two principal compounds PC described $79.1 \%$ of the variation (Figure 3). Regarding the biological activity, PC1 describes $36.9 \%$ of the variation among treatments separating the enzymatic inhibition positively in Melissa by $\alpha$-glucosidase and negatively in peppermint by $\alpha$-amylase, PC2 described $60.8 \%$ of the variation in the biological activity grouping positively the biological activity in mint with the activity $\alpha$-amylase, peppermint, thyme and mint with the activity $\alpha$-glucosidase and ECA. The HCA (Hierarchical Cluster Analysis) groupings that grouped the greatest amount of biological activities were microwave drying method in a positive way and freeze-drying method in a negative way. On the other hand, in Figure 4, PCA was used to classify plant material according to their phytochemical composition affected by drying methods. HCA allowed the formation of clusters for the different drying methods, in order to compare their influence on phytochemical composition for the plant material. Variation for the 3 drying methods were explained in a $32.7 \%$ by the PC1. Whereas, PC2 allowed the explanation of $60.2 \%$ of the variation in composition for fresh plant material. PC1 separated drying methods in relation to the phytochemical compounds. However, it was not possible to see a clear separation, and the same occurred for PC2. Therefore, HCA appeared to be the most suitable tool in separating drying methods with respect to their influence on phytochemical composition for plant material. Therefore, as Figures 1-4 show, there are large differences between the components in the case of fresh components and those after the different drying methods, which are hugely different in the technique used for this purpose. 


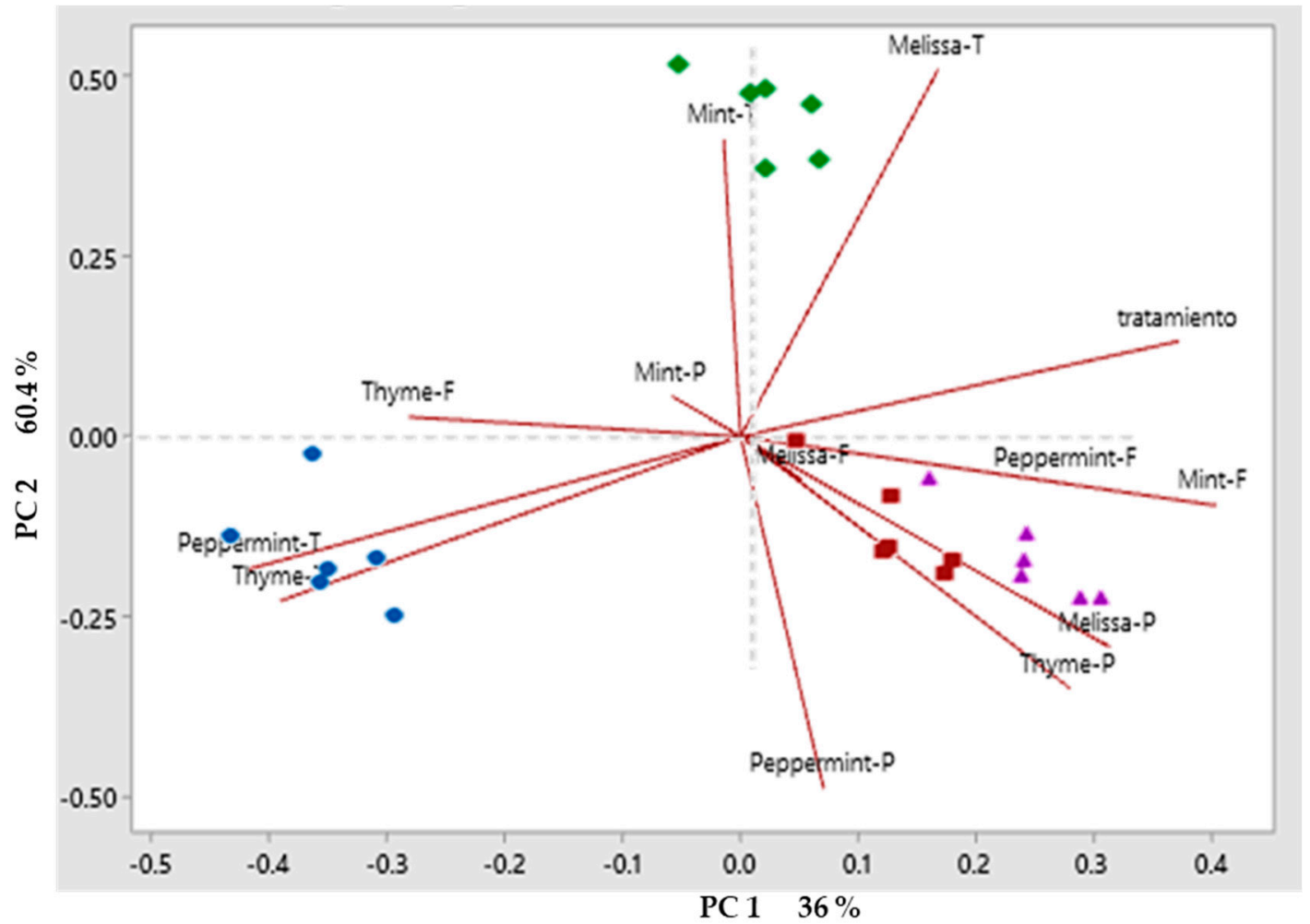

Figure 1. Principal component analysis (PCA) a) Phenolic compounds, flavonoids, tannins, by drying method and plant materials. [The different drying methods correspond to the Blue (Fresh plant), red (Microwave oven), green (Conventional) and violet (Freeze drying) icons] and [Acronyms per sample indicate P (Phenols), F (Flavonoids), and T (Tannins)] [Red line indicates the direction of the maximum variance of the data to orthogonal axes of each component].

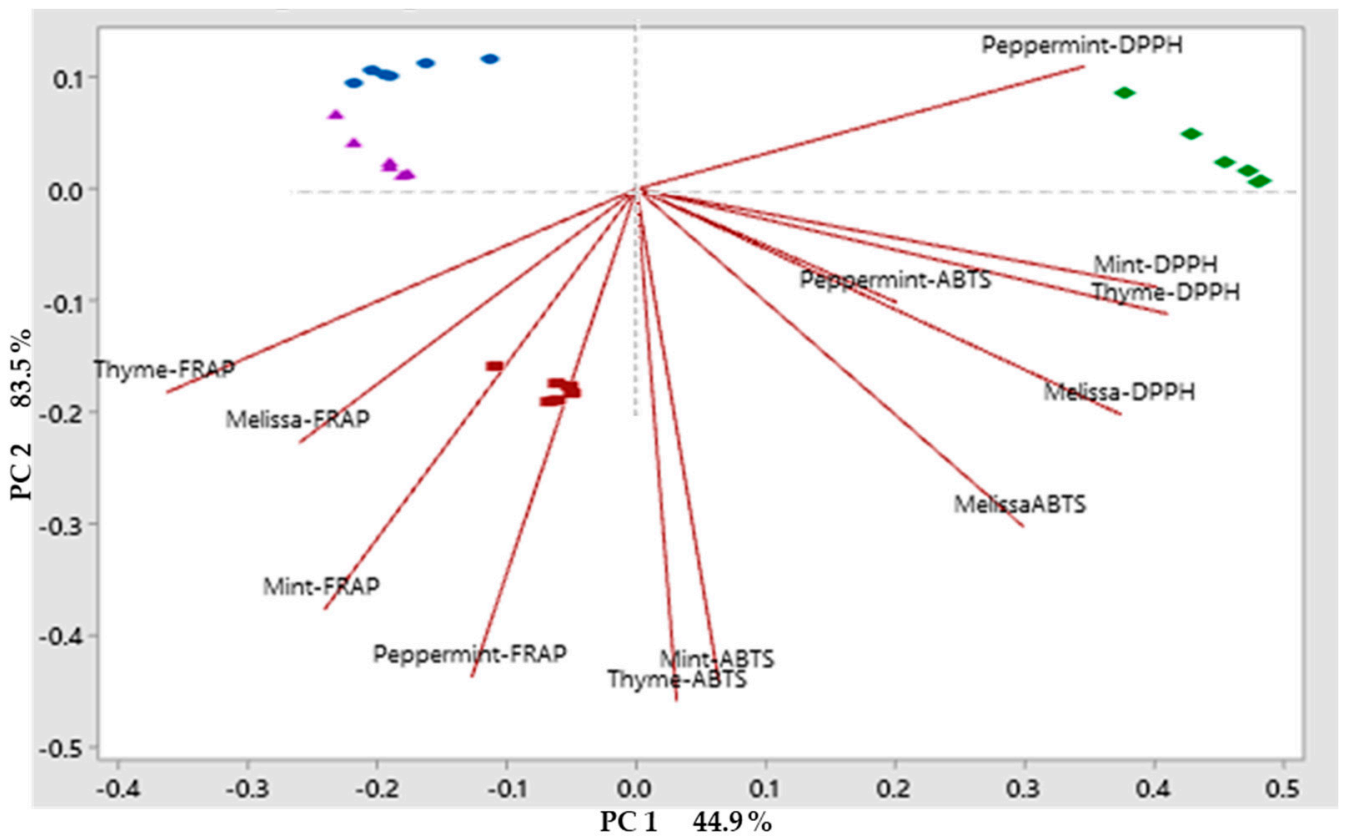

Figure 2. Principal component analysis (PCA) b) antioxidants capacity (ABTS, DPPH, FRAP), by drying method and plant material [the different drying methods correspond to the Blue (Fresh plant), red (Microwave oven), green (Conventional) and violet (Freeze drying) icons] [Red line indicates the direction of the maximum variance of the data to orthogonal axes of each component]. 


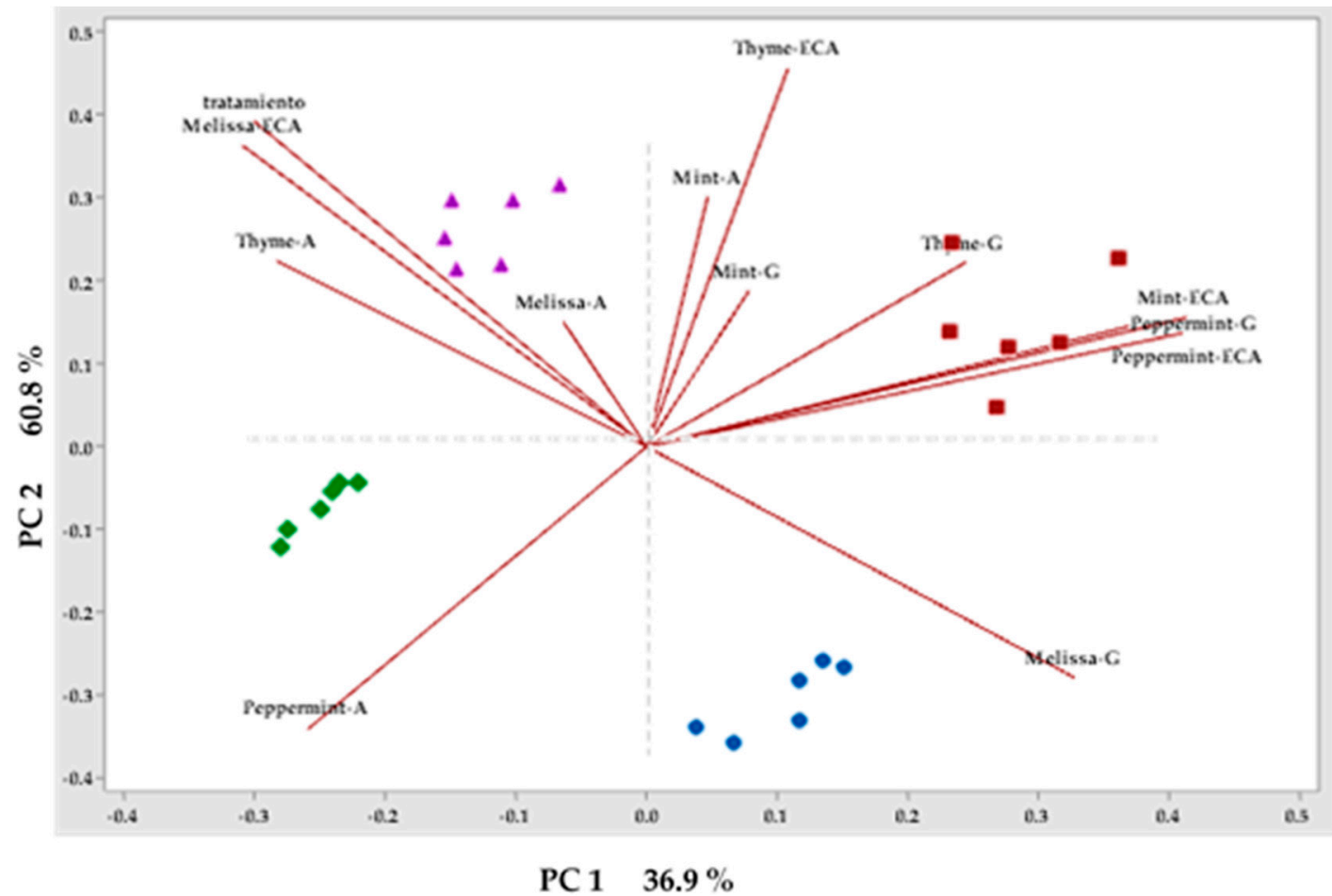

Figure 3. Principal component analysis (PCA) c) Biological activity ( $\alpha$-amylase, $\alpha$-glucoside and ACE) by drying method and plant materials [the different drying methods correspond to the Blue (Fresh plant), red (Microwave oven), green (Conventional) and violet (Freeze drying) icons] and [Acronyms per sample indicate A ( $\alpha$-amylase), G ( $\alpha$-glucosidase), and ECA (Angiotensin converting enzyme)] [Red line indicates the direction of the maximum variance of the data to orthogonal axes of each component.].

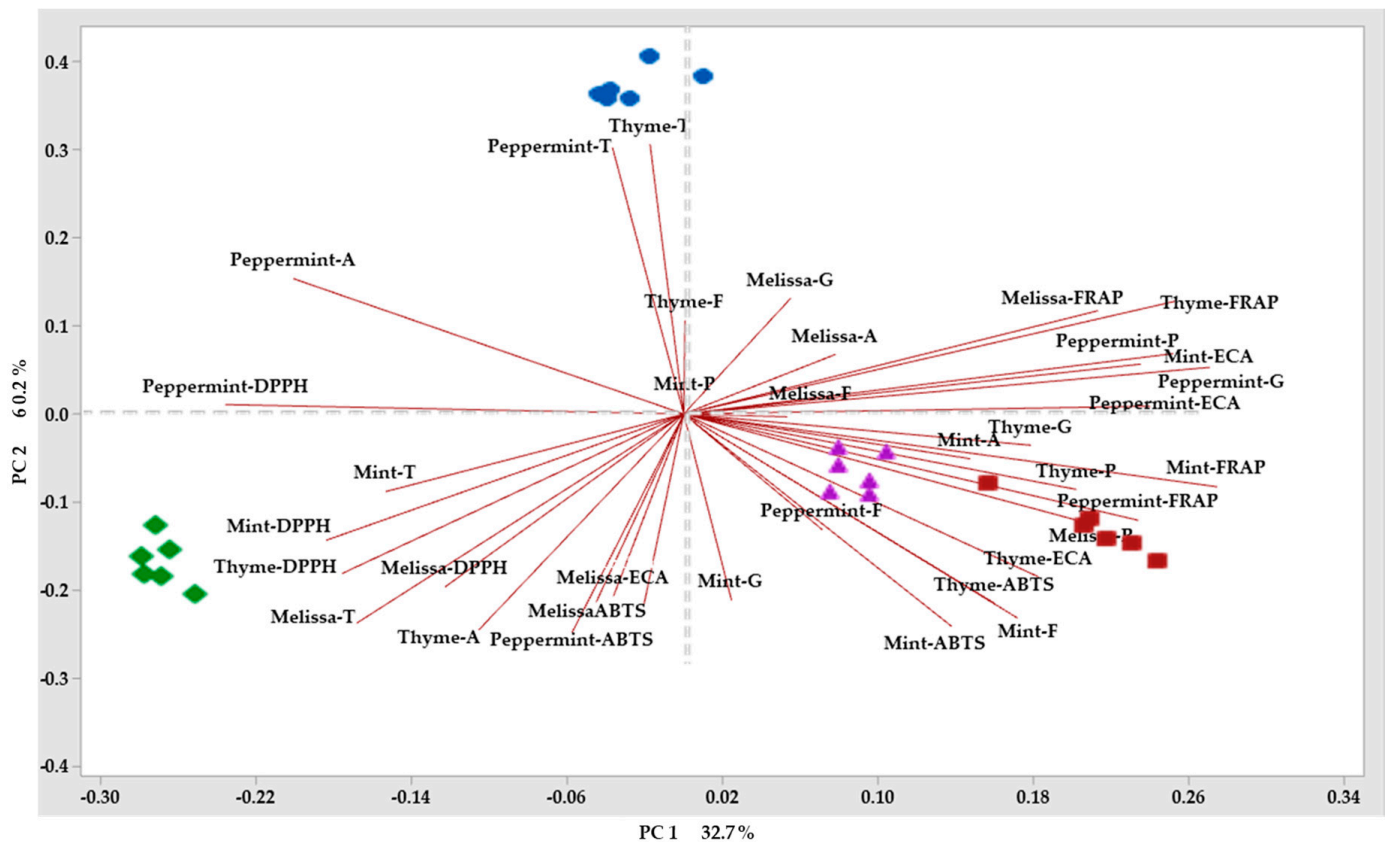

Figure 4. Principal component analysis (PCA) d) Phytochemical Compounds by drying method and plant materials [the different drying methods correspond to the Blue (Fresh plant), red (Microwave oven), green (Conventional) and violet (Freeze drying) icons] and [Acronyms per sample indicate P (Phenols), F (Flavonoids), T (Tannins), A ( $\alpha$-amylase), G ( $\alpha$-glucosidase), and ECA(Angiotensin converting enzyme)] [Red line indicates the direction of the maximum variance of the data to orthogonal axes of each component]. 


\section{Discussion}

The different types of drying that are carried out in the spices have an influence on the content of bioactive compounds. Some may favor the detection of biologically active constituents that were not present in the raw material [5]. The results showed that antioxidant activity is favored by microwave drying and freeze-drying. The positive influence on the antioxidant potential of the extracts could be due, among other factors, to the stress caused by the plant structure. The factors that cause stress in plants to name a few are water deficit, soil composition, and temperature [4]. In this case, the high temperatures of the microwaves exert stress on the spices, generating great pressure on the cell walls, while during freeze-drying, the stress is due to the damage caused by the formation of ice crystals [29]. In both cases (freeze-drying and microwave drying), drying causes cell wall degradation facilitating the removal of water $[18,21]$ and, in turn, the extraction of intracellular compounds, such as polyphenols. This would be a response to the high content of these Compounds in these drying methods. The polyphenols present in spices have positive effects on health, proving the effectiveness by in vitro tests of the elimination of free radicals (DPPH and ABTS) and the reduction of metal ions (FRAP) [30], in such a way that this could be an explanation of the antioxidant activities of spices. The biological activity of plants is shown to be useful for the treatment of various diseases, especially chronic non transmissible diseases such as diabetes. In the case of DMII, the inhibition of $\alpha$-amylase has been considered as one of the important mechanisms involved in the control of diabetes [31,32]. The results obtained in the $\alpha$-glucosidase test show that microwave-dried spices have increased hypoglycemic capacity in Melissa followed by microwave-dried mint. Melissa showed a significant reduction in blood glucose $(65 \% ; \mathrm{P}<0.05)$ in rats treated with the extract for 6 weeks [33] and in a study that included 62 patients who received capsules $M$. Officinalis $(700 \mathrm{mg} / \mathrm{d} ; n=31)$ twice a day for 12 weeks, a significant reduction in HbA1c (hemoglobin A1c) $(\mathrm{P}=0.002)$ was seen [8]. On the other hand, the inhibition of $\alpha$-amylase has demonstrated its effectiveness of use of phenolic compounds for the inhibition of this enzyme in some studies carried out in diabetic rats with aqueous peppermint extract significant hypoglycemic properties were found [34]. On the other hand, a trial was conducted with male offspring of non-diabetic mothers and mothers with severe streptozotocin-induced diabetes. It was found that the offspring of diabetic mothers, treated with mint, showed significantly reduced glucose levels [9]. However, the content of polyphenols, could participate in the glucose metabolism pathways related to the absorption of glucose in the intestine, the secretion of insulin by the $\beta$-cells of the islets, the regulation of liver glucose production, insulin receptor activity in insulin-sensitive tissues and glucose uptake, and regulation of intrahepatic glucose production [10]. Numerous studies have shown that hypoglycemic properties related to phytochemical content, 26 such compounds, polyphenols, show a fasting and postprandial blood glucose response have been investigated in animal models and in human studies [35]. It is also possible to consider the synergistic effect of polyphenolic compounds, which may have a positive effect on blood glucose [10]. On the other hand, another of the important chronic noncommunicable diseases is Arterial Hypertension (HT). An in vitro test of ACE inhibition was performed, showing in our study significant changes in vitro tests we can show that spices can have a transcendental role in the treatment of HT. In the review of the literature, no studies were carried out on the spices used in a study with rats and Melissa aqueous extract at different doses (50, 100 and $200 \mathrm{mg} / \mathrm{kg} /$ day) where no significant effect on pressure arterial was observed [13]. It is evident that the phytochemicals that we found in spices have an effect against noncommunicable diseases and the drying methods that were applied in this investigation help us to corroborate the conservation of these phytochemicals with the use of the proper drying method. Other hand, according to Śledź, et al. [36], the loss of polyphenolic compounds in oregano ranged between 71.6 and $78.4 \%$, depending on the microwave power applied, and increased when the microwave power was reduced. This can be related to the results of the samples analyzed since using this method of drying had losses of some phytochemical compounds, so it would now have to work with less power or less drying intervals. In some cases, as in mint, some authors also show data on the increase in polyphenols, attributing it to the breakdown of cellular components or ascorbic acid concentrations. 
Therefore, we must be careful with the techniques used in quantification of phenolic compounds by Folin-Ciocalteu's [16]. Some authors classify Melissa and Thyme as woody herbs, so this type of tissue acts as a barrier to the release of phenolic compounds in the extracts and therefore results in a lower antioxidant capacity. On the other hand, lyophilized samples were dried at a very low temperature $\left(-54{ }^{\circ} \mathrm{C}\right)$, and degrading enzymes could still be activated when they come in contact with moisture from any source, for example, probably from the air. In thyme, the difference in antioxidant capacity and total phenols between conventional drying and freeze-drying was greater. This is probably due to the fact that during conventional drying the leaves of the herbs are heated $\left(70^{\circ} \mathrm{C}\right)$ and their intercellular spaces collapse, releasing more phenolic compounds [19]. The results obtained from the ABTS, DPPH, FRAP trials showed a high degree of correlation. The highest correlation between the content of phenolic compounds and DPPH values was observed (Figure 4), as expected, as both tests followed the same principle of electron transfer based on the antioxidant effects against oxygen free radicals.

\section{Materials and Methods}

\subsection{Sample Preparation}

The herbs or spices (Melissa, thyme, peppermint, and mint) analyzed for this study were grown free of fertilizers and pesticides. The selection of these spices was made considering their good phytosanitary state (the spices should not have mold or any visible pest) and in a fresh state; the leaves and stems of the plants will be taken as part of the sample. In all cases, $1 \mathrm{~kg}$ of flowering stems were collected. Samples were collected in a full flowering period, in the experimental de la Autonomous University of Queretaro campus Amazcala. The collected samples were divided into four parts and different drying methods were applied. Once selected, they were freeze-dried, conventionally dried and microwaved, as well as subsequently stored in closed containers, thereby eliminating oxygen with $\mathrm{N}_{2}$ gas to eliminate $\mathrm{O}_{2}$ in the headspace and stored in fresh and dry spaces for analysis. On the other hand, fresh samples were only frozen with liquid nitrogen and kept frozen at $-18{ }^{\circ} \mathrm{C}$ for further analysis. The preparation of the sample for the analysis of phytochemical compounds the extraction will be carried out according to the methodology described by Cardador [37], $25 \mathrm{mg}$ of dry sample and $200 \mathrm{mg}$ of the fresh sample will be placed according to the case of study and added $2.5 \mathrm{~mL}$ of methanol to each sample, realizing samples in triplicate. They were kept free of light and stirred for $24 \mathrm{~h}$. Centrifuging at $5000 \mathrm{rpm} / 10 \mathrm{~min} / 4^{\circ} \mathrm{C}$, the pellet formed in the bottom was removed, leaving the supernatant. The sample is presented per $\mathrm{g}$ of dry sample.

\subsection{Drying Methods Used in Herbs and Spices}

Three drying methods were performed on each of the herbs and spices. Conventional drying will use a food dehydrator (Hamilton Beach 32100A, NC, USA) a temperature of $58^{\circ} \mathrm{C}$ for a period of $25 \mathrm{~h}$ [38]. The microwave drying process will undergo a sample of $30 \mathrm{Ghz} / 10 \mathrm{~s}$ drying in 10 consecutive intervals in a microwave (Mabe HMM70SW, Santiago, Chile) [39]. For freeze-drying, it was performed in a freeze dryer (Labconco FreeZone 4.5L model 230V, Kansas City, USA) with a temperature of $-50{ }^{\circ} \mathrm{C}$ with a vacuum system of $0.01 \mathrm{~atm}$ [40]. Table 4 shows the data of the parameters of each drying method. 
Table 4. Drying Parameters.

\begin{tabular}{|c|c|c|c|c|c|c|}
\hline \multirow[b]{2}{*}{ Drying Method } & \multirow[b]{2}{*}{ Plant Materials * } & \multirow[b]{2}{*}{ Moisture (\%) } & \multirow{2}{*}{$\begin{array}{l}\text { Drying } \\
\text { Time (h) }\end{array}$} & \multicolumn{3}{|c|}{ Weight for Analysis (mg) } \\
\hline & & & & $\begin{array}{l}\text { Phenolic } \\
\text { Compounds }\end{array}$ & $\begin{array}{l}\text { Antioxidant } \\
\text { Compounds }\end{array}$ & $\begin{array}{l}\text { Enzymatic } \\
\text { Inhibition }\end{array}$ \\
\hline \multirow{4}{*}{ Fresh } & Melissa & 72.5 & - & 200 & 200 & 200 \\
\hline & Peppermint & 76.3 & - & 200 & 200 & 200 \\
\hline & Thyme & 68.5 & - & 200 & 200 & 200 \\
\hline & Mint & 76.9 & - & 200 & 200 & 200 \\
\hline \multirow{4}{*}{$\begin{array}{l}\text { Microwave oven } \\
\text { (30 GhZ/10 range) }\end{array}$} & Melissa & 5.9 & $0.16 / 10$ range & 25 & 25 & 25 \\
\hline & Peppermint & 5.6 & $0.16 / 10$ range & 25 & 25 & 25 \\
\hline & Thyme & 5.2 & $0.16 / 10$ range & 25 & 25 & 25 \\
\hline & Mint & 5.6 & $0.16 / 10$ range & 25 & 25 & 25 \\
\hline \multirow{4}{*}{ Conventional $\left(58^{\circ} \mathrm{C}\right)$} & Melissa & 6.9 & 25 & 25 & 25 & 25 \\
\hline & Peppermint & 6.5 & 25 & 25 & 25 & 25 \\
\hline & Thyme & 7.1 & 25 & 25 & 25 & 25 \\
\hline & Mint & 6.4 & 25 & 25 & 25 & 25 \\
\hline \multirow{4}{*}{$\begin{array}{c}\text { Freeze-drying } \\
\left(-50^{\circ} \mathrm{C} / 0.012 \mathrm{~atm}\right)\end{array}$} & Melissa & 6.1 & 24 & 25 & 25 & 25 \\
\hline & Peppermint & 5.3 & 24 & 25 & 25 & 25 \\
\hline & Thyme & 5.9 & 24 & 25 & 25 & 25 \\
\hline & Mint & 5.2 & 24 & 25 & 25 & 25 \\
\hline
\end{tabular}

* Each sample adjusted the data with the dilution factor. Each data of the analysis was modified with respect to its percentage of humidity. The sample is presented per $g$ of dry weight (DW).

\subsection{Determination of Total Phenolic Compounds}

The total phenol content was determined using the Folin-Ciocalteu spectrophotometric method [6] modified for use in 96-well microplate. In quantification, an aliquot of the methanolic extract $(4 \mu \mathrm{L})$ mixed, $250 \mu \mathrm{L}$ of the Folin-Ciocalteu reagent $(1 \mathrm{~N})$, add $1250 \mu \mathrm{L}$ of Na2CO3 (20\%) were mixed and allowed to stand in the dark for $2 \mathrm{~h}$ at room temperature. Subsequently, the absorbance ismeasured at $760 \mathrm{~nm}$ in a spectrophotometer (MULTISKAN GO, Thermo Fisher Scientific, Finland). The results are expressed as mg equivalent of gallic acid/g DW.

\subsection{Determination of Total Flavonoids}

The spectrophotometric method used for the quantification of total flavonoids in methanolic extracts was determined by Oomah, et al. [41]. $50 \mu \mathrm{L}$ of the methanolic extract was mixed with $180 \mu \mathrm{L}$ of methanol and $20 \mu \mathrm{L}$ of $1 \% 2$-aminoethyldi-phenylborate solution in a 96-well plate. The experiments were performed in triplicate. The absorbance will be measure at $404 \mathrm{~nm}$. Expressing the results in rutine hydrate mg equivalent/g DW.

\subsection{Determination of Total Tannins}

The quantification of total condensed tannins was performed following the procedure described by Feregrino-Pérez, et al. [42], modified for 96-well microplate. $50 \mu \mathrm{L}$ of the methanolic extract was placed in the 96-well microplate with $200 \mu \mathrm{L}$ of $1: 1$ solution $(v / v)(1 \%$ vanillin - $\mathrm{HCl} 8$. The number of condensed tannins in plate reader was quantified (MULTISKAN GO, Thermo Fisher Scientific, Finland) at $492 \mathrm{~nm}$. Expressed in mg equivalent of (+) catechin/g DW and the samples were analyzed in triplicate.

\subsection{Determination of Antioxidant Capacity}

\subsubsection{DPPH Method Antioxidant Capacity}

The quantification of DPPH antioxidant capacity (2,2-Diphenyl-1-picrylhydrazyl) was carried out as described by Zenil, et al. [43]. A total of $20 \mu \mathrm{L}$ of the methanolic extract was mixed with $200 \mu \mathrm{L} \mathrm{DPPH}$ in a 96-well plate. The experiments were performed in triplicate. It was measured at an absorbance of $520 \mathrm{~nm}$ at a time of $30 \mathrm{~min}$. The results were expressed in $\mathrm{mg}$ equivalent of trolox/g DW or in \% radical inhibition $\%$ inhibicion $=\frac{(\text { Abs.Inicial })-(\text { Abs.Final })}{\text { Abs.Inicial }} * 100$. 


\subsubsection{ABTS Method Antioxidant Capacity}

The spectrophotometric method for the quantification of antioxidant capacity by ABTS (2,2'-azino-bis- (3-ethyl benzothiazolin-6-ammonium sulphonate) was performed following the Re method [44]. For quantification, $230 \mu \mathrm{L}$ of ABTS with $20 \mu \mathrm{L}$ of the sample in a 96-well microplate was measured at $734 \mathrm{~nm}$ with a plate reader (MULTISKAN GO, Thermo Fisher Scientific, Finland), analyzing the samples in triplicate. The results are expressed in $\mathrm{mg}$ equivalent of Trolox/g DW or in $\%$ radical inhibition $\%$ inhibicion $=\frac{(\text { Abs.Inicial })-(\text { Abs.Final })}{\text { Abs.Inicial }} * 100$.

\subsubsection{Antioxidant Capacity FRAP Method}

The quantification of antioxidant capacity by FRAP (Ferric Reducing/Antioxidant Power) was carried out following the Olaya method [45]. The antioxidant capacity was determined by taking $20 \mu \mathrm{L}$ of the methanolic extract and mixing with $230 \mu \mathrm{L}$ of 2,4,6-tri(2-pyridyl)-s-triazine in a microplate. It was measured at $595 \mathrm{~nm}$ in a plate reader (MULTISKAN GO, Thermo Fisher Scientific, Finland), analyzing the sample in triplicate. The results were expressed in mg equivalent of trolox/g DW or in $\%$ radical inhibition $\%$ inhibicion $=\frac{(\text { Abs.Inicial })-(\text { Abs.Final })}{\text { Abs.Inicial }} * 100$.

\subsection{Biological Activity}

\subsection{1. $\alpha$-Amylase Inhibition}

The quantification of pancreatic $\alpha$-amylase (Sigma Aldrich chemical A8273, St. Louis, Missouri, USA) was performed following the procedure described by MezaandValdés [46], modified for use for 96-well microplate. $450 \mu \mathrm{L}$ of phenolic extract and $450 \mu \mathrm{L}$ of $\alpha$-amylase solution $(0.5 \mathrm{mg} / \mathrm{mL})$ are mixed in Eppendorf tubes, covered $25^{\circ} \mathrm{C} / 10 \mathrm{~min}$. Subsequently, $450 \mu \mathrm{L}$ of starch are added and cover at $25^{\circ} \mathrm{C} / 10 \mathrm{~min}$. Finally, $300 \mu \mathrm{L}$ of DNS (3,5-Dinitro-2-hydroxybenzoic acid) was added and subsequently heated in a water bath at $180^{\circ} \mathrm{C} / 5 \mathrm{~min}$. Allow to cool to room temperature and placed in the 96-well microplate. Absorbance was measured at $540 \mathrm{~nm}$ in a plate reader (MULTISKAN GO).

\subsection{2. $\alpha$-Glucosidase Inhibition}

The $\alpha$-glucosidase inhibition was performed following the procedure described by Ranilla et al. [4], modified for 96 -well microplate. An amount of $50 \mu \mathrm{L}$ of the methanolic extract, $50 \mu \mathrm{L}$ of $0.1 \mathrm{M}$ potassium phosphate buffer $\mathrm{pH} 6.9$ and $100 \mu \mathrm{L}$ of the $\alpha$-glucosidase solution $(1.0 \mathrm{U} / \mathrm{mL}$ ) (Sigma Aldrich Chemical G3651, St. Louis, Missouri, USA) were mixed. They were covered at $25^{\circ} \mathrm{C} / 10 \mathrm{~min}$ in the microplate. Its absorbance at $405 \mathrm{~nm}$ was measured in a plate reader (MULTISKAN GO, Thermo Fisher Scientific, Finland). $50 \mu \mathrm{L}$ of the $5 \mathrm{mM}$ D-nitrophenyl- $\alpha$-glucopyranoside solution is then added and placed at $25^{\circ} \mathrm{C} / 5 \mathrm{~min}$, again its absorbance at $405 \mathrm{~nm}$ is recorded. Each experiment was performed in triplicate.

\subsubsection{Antihypertensive Activity}

Inhibition of ACE (angiotensin-converting enzyme) was performed following the procedure described by Salazar Aranda, et al. [47], modified for 96-well microplate. $100 \mu \mathrm{L}$ of the $\mathrm{N}$-(3-(2-frapgglacryloy)) $5 \times 10^{-4} \mathrm{M}$ (Sigma Aldrich chemical F7131, St. Louis, Missouri, USA) solution, $125 \mu \mathrm{L}$ of the methanolic extract, $15 \mu \mathrm{L}$ of the TRIS-HCl buffer and $10 \mu \mathrm{L}$ of ACE were mixed. The absorbance at $345 \mathrm{~nm}$ was measured for $5 \mathrm{~min}$ in a plate reader (MULTISKAN GO, Thermo Fisher Scientific, Finland). Analyzing the samples in triplicate.

\subsection{Statistical Analysis}

All the results obtained in this investigation were shown as the mean \pm standard error. Data were evaluated using unidirectional ANOVA and changes between processing were evaluated by comparing means using the Tukey test. The level of statistical significance was considered at $p<0.05$. Principal 
component analysis (PCA) with a self-scaling using the medium centering method and hierarchical clustering analysis (HCA) with centroid link grouping for the responses of the identified compounds were performed in order to characterize the effect of the treatments in the content of bioactive compounds, using XLSTAT 2014.05.03 (XLSTAT and Addinsoftare Registered Trademarks of Addinsoft. https://www.xlstat.com)

\section{Conclusions}

This study shows that the preliminary phytochemical analysis of the extracts demonstrated the presence of different groups of secondary metabolites (flavonoids, tannins and phenols). Therefore, in this paper, the vegetative material shows significant differences superior to the fresh vegetative material after applying the microwave drying and freeze-drying methods. On the other hand, the conventional method a thermal and/or enzymatic degradation of phenolic compounds was observed in the vegetative material. This effect was due to the leaves drying up at temperatures between 50 and $100{ }^{\circ} \mathrm{C}$ suffered an enzymatic and thermal degradation in the main factors of the reduction of phenolic compounds. Regarding the results obtained, it is concluded that the biological activity is affected by the type of drying with which the vegetative material. These drying methods significantly influence both positively and negatively the properties of the plant material, altering the amounts of phytochemicals present as Phenolic compounds and play an important role in enzyme inhibition and antioxidant capacity. Therefore, we can conclude that microwave drying, and freeze-drying have positive effects by increasing the percentages of inhibition of ACE, $\alpha$-glucosidase, and $\alpha$-amylase that contribute to the treatment of HTA and DMII. For all the herbs analyzed, drying was carried out mainly with decreasing rates. Initially, there was a relatively short phase with a higher moisture removal rate, with a high moisture content in the material. This phenomenon resulted from a greater ability to absorb microwave energy typical of material that contains more water. On the other hand, freeze-drying is used for the reliable preservation of a wide variety of heat-sensitive products and demands the highest standards of reliability and control. Unfortunately, the high porosity of dry materials has a negative effect on storage stability. Therefore, freeze-drying materials need to be stored in an airtight package. The freeze-drying process remains expensive, which restricts its application.

Author Contributions: S.N.J.-G., M.A.V.-C.: data acquisition; Analysis and interpretation of data; and drafting of the manuscript, conceptualization, data retention, and formal analysis; A.A.F.-P., J.F.G.-T., L.M.C.-M., X.S.R.-G., V.B.-C. obtained funds and responsibility for managing and coordinating the planning and execution of the research activity and revision of the manuscript. All authors assisted in the critical review of this manuscript, approved the version presented for publication and agreed to be responsible for all aspects of the article. All authors have read and agreed to the published version of the manuscript.

Funding: PRODEP funds were received as NPTC-2017 for the realization of the project and the support to the Autonomous University of Queretaro and the University of Guanajuato for the support.

Acknowledgments: Wants to thank the collaboration of the Autonomous University of Queretaro, especially the Metabolites and nanocomposites laboratory for the support with the teams to develop some experimental techniques, also the Itzel Student Alejandra Perez Vega for the support in the experimental part of this work and the University from Guanajuato for facilitating the student's stay

Conflicts of Interest: The authors declare no conflict of interest.

\section{References}

1. Sood, P.; Shri, R. A review on ethnomedicinal, phytochemical and pharmacological aspects of Myrica esculenta. Indian J. Pharm. Sci. 2018, 80, 2-13.

2. Alexa, E.; Danciu, C.; Radulov, I.; Obistioiu, D.; Sumalan, R.M.; Morar, A.; Dehelean, C.A. Phytochemical screening and biological activity of Menthax piperita L. and Lavandula angustifolia mill. extracts. Anal. Cell. Pathol. 2018, 2018, 2678924. [CrossRef]

3. Sharafi, S.M.; Rasooli, I.; Owlia, P.; Taghizadeh, M.; Astaneh, S.D.A. Protective effects of bioactive phytochemicals from Mentha piperita with multiple health potentials. Pharmacogn. Mag. 2010, 6, 147. 
4. Ranilla, L.G.; Kwon, Y.-I.; Apostolidis, E.; Shetty, K. Phenolic compounds, antioxidant activity and in vitro inhibitory potential against key enzymes relevant for hyperglycemia and hypertension of commonly used medicinal plants, herbs and spices in Latin America. Bioresour. Technol. 2010, 101, 4676-4689. [CrossRef] [PubMed]

5. Abdul Qadir, M.; Shahzadi, S.K.; Bashir, A.; Munir, A.; Shahzad, S. Evaluation of phenolic compounds and antioxidant and antimicrobial activities of some common herbs. Int. J. Anal. Chem. 2017, 2017, 3475738. [CrossRef] [PubMed]

6. Agbor, G.A.; Oben, J.E.; Ngogang, J.Y.; Xinxing, C.; Vinson, J.A. Antioxidant capacity of some herbs/spices from Cameroon: A comparative study of two methods. J. Agric. Food Chem. 2005, 53, 6819-6824. [CrossRef] [PubMed]

7. Kador, P.F. Topical applied nutraceutical antioxidant formulation reduces ocular oxidative stress. Funct. Foods Health Dis. 2017, 7, 68-87. [CrossRef]

8. Asadi, A.; Shidfar, F.; Safari, M.; Hosseini, A.F.; Fallah Huseini, H.; Heidari, I.; Rajab, A. Efficacy of Melissa officinalis L.(lemon balm) extract on glycemic control and cardiovascular risk factors in individuals with type 2 diabetes: A randomized, double-blind, clinical trial. Phytother. Res. 2019, 33, 651-659. [CrossRef] [PubMed]

9. Barbalho, S.M.; Damasceno, D.C.; Spada, A.P.M.; Silva, V.S.d.; Martuchi, K.A.; Oshiiwa, M.; Machado, F.; Farinazzi, M.; Mendes, C.G. Metabolic profile of offspring from diabetic Wistar rats treated with Mentha piperita (peppermint). Evid. Based Complement. Altern. Med. 2011, 2011, 430237. [CrossRef] [PubMed]

10. Ge, Q.; Chen, L.; Chen, K. Treatment of diabetes mellitus using iPS cells and spice polyphenols. J. Diabetes Res. 2017, 2017, 5837804. [CrossRef] [PubMed]

11. Hwang, S.H.; Kwon, S.H.; Kim, S.B.; Lim, S.S. Inhibitory activities of Stauntonia hexaphylla leaf constituents on rat lens aldose reductase and formation of advanced glycation end products and antioxidant. BioMed Res. Int. 2017, 2017, 4273257. [CrossRef] [PubMed]

12. Hasanein, P.; Riahi, H. Antinociceptive and antihyperglycemic effects of Melissa officinalis essential oil in an experimental model of diabetes. Med. Princ. Pract. 2015, 24, 47-52. [CrossRef] [PubMed]

13. Joukar, S.; Asadipour, H. Evaluation of Melissa officinalis (Lemon Balm) effects on heart electrical system. Res. Cardiovasc. Med. 2015, 4, e27013. [CrossRef]

14. Rakhi, N.; Tuwani, R.; Mukherjee, J.; Bagler, G. Data-driven analysis of biomedical literature suggests broad-spectrum benefits of culinary herbs and spices. PLoS ONE 2018, 13, e0198030. [CrossRef]

15. Ganesan, K.; Xu, B. A critical review on polyphenols and health benefits of black soybeans. Nutrients 2017, 9, 455. [CrossRef]

16. Figiel, A.; Michalska, A. Overall quality of fruits and vegetables products affected by the drying processes with the assistance of vacuum-microwaves. Int. J. Mol. Sci. 2017, 18, 71. [CrossRef]

17. Nawirska-Olszańska, A.; Stępień, B.; Biesiada, A.; Kolniak-Ostek, J.; Oziembłowski, M. Rheological, chemical and physical characteristics of golden berry (Physalis peruviana L.) after convective and microwave drying. Foods 2017, 6, 60 .

18. Shofian, N.M.; Hamid, A.A.; Osman, A.; Saari, N.; Anwar, F.; Pak Dek, M.S.; Hairuddin, M.R. Effect of freeze-drying on the antioxidant compounds and antioxidant activity of selected tropical fruits. Int. J. Mol. Sci. 2011, 12, 4678-4692. [CrossRef]

19. Hossain, M.; Barry-Ryan, C.; Martin-Diana, A.B.; Brunton, N. Effect of drying method on the antioxidant capacity of six Lamiaceae herbs. Food Chem. 2010, 123, 85-91. [CrossRef]

20. Amiri Chayjan, R.; Kaveh, M.; Khayati, S. Modeling drying characteristics of hawthorn fruit under microwave-convective conditions. J. Food Process. Preserv. 2015, 39, 239-253. [CrossRef]

21. Tummanichanont, C.; Phoungchandang, S.; Srzednicki, G. Effects of pretreatment and drying methods on drying characteristics and quality attributes of Andrographis paniculata. J. Food Process. Preserv. 2017, 41, e13310. [CrossRef]

22. Loh, Z.H.; Lim, Y.Y. Drying effects on antioxidant activity, enzyme activity, and phytochemicals of avocado (Persea americana) leaves. J. Food Process. Preserv. 2018, 42, e13667. [CrossRef]

23. Asekun, O.; Grierson, D.; Afolayan, A. Effects of drying methods on the quality and quantity of the essential oil of Mentha longifolia L. subsp. Capensis. Food Chem. 2007, 101, 995-998. [CrossRef]

24. Ciurzyńska, A.; Lenart, A. Freeze-drying-application in food processing and biotechnology-a review. Pol. J. Food Nutr. Sci. 2011, 61, 165-171. [CrossRef]

25. Mujumdar, A.S. Handbook of Industrial Drying; CRC press: New York, NY, USA, 2014. 
26. Orphanides, A.; Goulas, V.; Gekas, V. Drying technologies: Vehicle to high-quality herbs. Food Eng. Rev. 2016, 8, 164-180. [CrossRef]

27. Chua, L.Y.; Chong, C.H.; Chua, B.L.; Figiel, A. Influence of drying methods on the antibacterial, antioxidant and essential oil volatile composition of herbs: A review. Food Bioprocess. Technol. 2019, 12, 450-476. [CrossRef]

28. Omojokun, O.S.; Oboh, G.; Ademiluyi, A.O. Effects of drying on cholinesterases and angiotensin-I converting enzyme inhibitory potential and phenolic constituents of African mistletoe (Loranthus bengwensis L) leaves from kolanut host tree. J. Food Biochem. 2018, 42, 1. [CrossRef]

29. Russo, R.; Pucci, L.; Giorgetti, L.; Árvay, J.; Vizzarri, F.; Longo, V.; Pozzo, L. Polyphenolic characterisation of plant mixture (Lisosan ${ }^{\circledR}$ Reduction) and its hypocholesterolaemic effect in high fat diet-fed mice. Nat. Prod. Res. 2019, 33, 651-658. [CrossRef]

30. Park, Y.J.; Baek, S.-A.; Choi, Y.; Kim, J.K.; Park, S.U. Metabolic profiling of nine Mentha species and prediction of their antioxidant properties using chemometrics. Molecules 2019, 24, 258. [CrossRef]

31. El-Abhar, H.S.; Schaalan, M.F. Phytotherapy in diabetes: Review on potential mechanistic perspectives. World J. Diabetes 2014, 5, 176. [CrossRef]

32. Bahadoran, Z.; Mirmiran, P.; Azizi, F. Dietary polyphenols as potential nutraceuticals in management of diabetes: A review. J. Diabetes Metab. Disord. 2013, 12, 43. [CrossRef]

33. Chung, M.J.; Cho, S.-Y.; Bhuiyan, M.J.H.; Kim, K.H.; Lee, S.-J. Anti-diabetic effects of lemon balm (Melissa officinalis) essential oil on glucose-and lipid-regulating enzymes in type 2 diabetic mice. Br. J. Nutr. 2010, 104, 180-188. [CrossRef] [PubMed]

34. Bayani, M.; Ahmadi-hamedani, M.; Javan, A.J. Study of hypoglycemic, hypocholesterolemic and antioxidant activities of Iranian Mentha spicata leaves aqueous extract in diabetic rats. Iran. J. Pharm. Res. IJPR 2017, 16, 75. [PubMed]

35. Hanhineva, K.; Törrönen, R.; Bondia-Pons, I.; Pekkinen, J.; Kolehmainen, M.; Mykkänen, H.; Poutanen, K. Impact of dietary polyphenols on carbohydrate metabolism. Int. J. Mol. Sci. 2010, 11, 1365-1402. [CrossRef] [PubMed]

36. Śledź, M.; Nowacka, M.; Wiktor, A.; Witrowa-Rajchert, D. Selected chemical and physico-chemical properties of microwave-convective dried herbs. Food Bioprod. Process. 2013, 91, 421-428. [CrossRef]

37. Cardador-Martínez, A.; Loarca-Piña, G.; Oomah, B.D. Antioxidant activity in common beans (Phaseolus vulgaris L.). J. Agric. Food Chem. 2002, 50, 6975-6980.

38. Serpa, A.M.; Martínez, D.C.C.; Osorio, D.C.V.; Llanos, G.A.H. Efecto de la liofilización sobre las propiedades técnico funcionales de la fibra dietaria y el contenido de vitamina $C$ presentes en la guayaba pera (Psidium Guajava L.). Rev. Investig. Apl. 2016, 9, 70-79.

39. Della, P. Secado de alimentos por métodos combinados: Deshidratación osmótica y secado por microondas y aire caliente. Ciudad Autónoma de Buenos Aires 2010. Available online: https://docplayer.es/7266922-Secado-de-alimentos-por-metodos-combinados-deshidratacionosmotica-y-secado-por-microondas-y-aire-caliente.html (accessed on 31 March 2020).

40. Cortés, M.; Herrera, E.; Rodríguez, E. Optimización experimental del proceso de liofilización de uchuva adicionada con componentes activos por impregnación al vacío. Vitae 2015, 22, 47-56. [CrossRef]

41. Oomah, B.D.; Cardador-Martínez, A.; Loarca-Piña, G. Phenolics and antioxidative activities in common beans (Phaseolus vulgaris L.). J. Sci. Food Agric. 2005, 85, 935-942. [CrossRef]

42. Feregrino-Pérez, A.A.; Berumen, L.C.; García-Alcocer, G.; Guevara-Gonzalez, R.N.G.; Ramos-Gomez, M.; Reynoso-Camacho, R.A.; Acosta-Gallegos, J.A.; Loarca-Piña, G. Composition and chemopreventive effect of polysaccharides from common beans (Phaseolus vulgaris L.) on azoxymethane-induced colon cancer. J. Agric. Food Chem. 2008, 56, 8737-8744.

43. Zenil, L.; Colinas, L.; Bautista, B.; Vázquez, R.; Lozoya, S.; Martínez, D. Total phenols and antioxidant capacity estimated with DPPH/ABTS assays in roses on preservative solutions. Rev. Mex. de Cienc. Agrícolas 2014, 5, 1029-1039.

44. Re, R.; Pellegrini, N.; Proteggente, A.; Pannala, A.; Yang, M.; Rice-Evans, C. Antioxidant activity applying an improved ABTS radical cation decolorization assay. Free Radic. Biol. Med. 1999, 26, 1231-1237. [CrossRef]

45. Olaya Zea, J.A.; Restrepo Sánchez, L.P. Study of phenolic compounds and antioxidant activity of guava in different stage of ripening. Acta Biológica Colomb. 2012, 17, 611-624. 
46. Meza, D.L.M.; Valdés, R.M. Inhibición in vitro de las enzimas alfa-amilasa y lipasa pancreática por fracciones fenólicas de extractos etanólicos de hojas de Yacón (Smallanthus sonchifolius Poepp. \& Endl). Av. En Química 2015, 10, 33-40.

47. Salazar Aranda, R.; Rodríguez, T.; Yael, C.; Alanís Garza, B.A.; Pérez López, L.A.; Waksman de Torres, N. Evaluación de la actividad biológica de productos herbolarios comerciales. Med. Univ. 2009, 11, 156-164.

Sample Availability: Samples of processed by each drying method are available from the authors.

(C) 2020 by the authors. Licensee MDPI, Basel, Switzerland. This article is an open access article distributed under the terms and conditions of the Creative Commons Attribution (CC BY) license (http://creativecommons.org/licenses/by/4.0/). 